\title{
THE USE OF PREDICTION \\ IN TEACHING THE GERMAN VERB
}

\author{
JAMES W. MARCHAND \\ University of Michigan
}

Among the recent techniques evolved from an attempt to exploit the findings of linguistic science for the teaching of languages, the use of the concept of determination and prediction must be considered one of the most fruitful. It has received notice in papers on pedagogy as well as in articles on linguistics. ${ }^{1}$ The present paper is an attempt to explore the possibilities of this concept, and techniques of teaching based on it, for the solution of that most difficult of pedagogical problems, the teaching of the German verb system.

Recently, there have been two attempts at using techniques of prediction in teaching the German verb, one by a descriptive linguist, one by a language teacher. ${ }^{2}$ We may be able to get a better idea of the values of a method based on the concept if we briefly review these two articles.

Halle shows that a better description of the German verb can be effected if one takes the stem of the preterite as a base rather than the traditional infinitive stem. It is far simpler for both the student and the linguist to operate with Halle's rather restricted number of rules than with the large number necessary for prediction of the preterite form from the infinitive. That is, given the verb / varden/ weiden 'to graze,' one does not know whether to form the preterite as */'vi:t/ *wied by analogy with /'కardən/ scheiden 'separate': /'ši:t/ schied, or as */'vit/ * witt by analogy with/'šnardən/ schneiden 'cut':

\footnotetext{
${ }^{1}$ L. Bloomfield, Language,New York, 1933, p. 218 f.; L. Hjelmslev, Prolegomena to a Theory of Language, trans. F. J. Whitfield, Memoir 7 of International Journal of American Linguistics, January, 1953, p. 21 ff.; J. Kurylowicz, "La nature des procès dits 'analogiques,'” Acta Linguistica V (1945-49) 15-37; M. Halle, “The German Conjugation," Word IX (1953) 45-53; C. V. Pollard, "The Weak Verb - How to Recognize It in the Infinitive," German Quarterly XXVI (1953) 241-245; F. L. Woods, "The Weak Verb - How to Recognize It in the Infinitive," German Quarterly XXVI (1954) 175-177; C. V. Pollard, "Infinitives of Weak Verbs - A Reply," German Quarterly XXVII (1954) 178 f.

${ }^{2}$ Halle, "The German Conjugation;" Pollard, "The Weak Verb - How to Recognize It in the Infinitive."
} 


\section{PREDICTION IN TEACHING THE GERMAN VERB}

/'šnit/schnitt, or as/'vardətə/weidete by analogy with/'krardən/ kreiden :/'kraidetə/kreidete. Once given the preterite /'vardato/ weidete, however, one has no trouble predicting the infinitive, the present stem, and the past participle.

Pollard attempts to set up rules which will allow us to predict from the infinitive. Exploiting the fact that a great part of the ablaut classes has developed regularly from Germanic to modern German, he sets up rules which allow him to predict with a great deal of surety, for verbs which do not contain $e i$, $i e, e$, or $a$ as stem vowel, the preterite and past participle. He affirms that the use of his prediction classes, which are much less scientifically set up than Halle's, and which admit of numerous exceptions, lightens the load of memorization immeasurably for the student. Thus, if the student knows that almost all verbs with the stem vowel $o, a u, e u, u$, umlauted vowel, and $i$ (without a following nasal) are weak, and if he is given the few exceptions, he then knows a large percentage of the German verbs. Pollard affirms that it is better to start with the weak ('regular') verbs and then to proceed to the strong ('irregular') verbs.

The basic error in Halle's approach, and in some other attempts to use prediction in teaching, is that no cognizance is taken of the trend of analogy in the language. If this is true, then linguistics has been only partly exploited for pedagogical use. Jerzy Kurylowicz has provided us with a set of premises which allow us to determine the trend of analogy without appealing to any of the teleological arguments so often cited in discussions of analogy. ${ }^{3}$ It results from his second rule: "Les actions dites 'analogiques' suivent la direction: formes de fondation $\rightarrow$ formes fondées, dont le rapport découle de leurs sphères d'emploi," that any analogy in modern German will follow the direction: present $\rightarrow$ preterite, rather than the direction: preterite $\rightarrow$ present. ${ }^{4}$ This is to be seen on the

${ }^{3}$ This article, which has been neglected by linguists and pedagogues alike, deserves attention; it marks a milestone in historical linguistics (cf. the review of Kurylewicz' Accentuation des langues indo-européennes by A. Martinet in Word LX (1953) 282-286; Martinet accepts Kurylowicz' rules of analogy.

"Kurylowicz, "La nature des procès dits "analogiques," p. 23. Since the present stem can express past time (historical present, present perfect, present with seit, schon), whereas the preterite cannot express present time, it follows from this rule that analogy will go in the direction of present $\rightarrow$ preterite. 
practical level when one tries to apply Halle's rules to actual cases. Given the utterance /"er 'ri:f/er rief 'he called,' one might mistakenly form the present /'er 'raift/er reift 'he matures,' in which case the meaning would be radically changed and communication would break down. Numerous examples come to mind: /er 'zo:k/ er sog 'he sucked': /'er 'si:kt/ er siegt 'he is victorious' (for er saugt); /'er bə'vo:k/ er bewog 'he moved': /'er ba'vi:kt/ er bewiegt (?) 'he encradles (?)' (for er bewegt); /'er 'šli:f/ er schlief 'he slept': /'er 'šlarft/ er schleift 'he sharpens' (for er schläft). As is seen, a great deal of memory work is required here also.

Pollard's approach, however (using only the predictions for the first five classes), avoids the formation of forms which are not understandable to the German. That is, "Er rufte den Mann," whatever its extra-linguistic 'meaning' might be, is understandable to the German, and it serves the purpose of communication quite adequately. By first teaching the weak verb, one in effect reinforces the effect of analogy, while providing for the conjugation of at least seventy-five percent of the German verbs. The student will then very seldom make analogies on the basis of the strong verbs he later learns. If he does make these analogies, he will probably again form preterites which are intelligible to the German. "Er frug den Mann" may carry certain unpleasant overtones for the educated German, but it is understandable, and is a form used by many Germans. Analogies on the strong verb should be avoided, however, and the student should be cautioned against them. "Das Pferd wied auf dem Feld (for, "Das Pferd weidete auf dem Feld.")" is not understandable to the German, who mistakes it for: "Das Pferd wiehert auf dem Feld." 5

Thus, as will have been seen, Pollard's predictions are superior in situations where active recall is necessary, in spite of their scientific inadequacy. If we add a few extra restrictions $(e i+l, m, n, r$ are weak [exception scheinen], $i e+l$, $m, n$ are weak, strong verbs of class I and II usually end in a single consonant), we çan use it with a fair degree of certainty. In a situation where passive 'recognition alone is required, Halle's system is superior in some ways to Pollard's. In a reading course, such as the one given at the University of Mich-

${ }^{5}$ The sentence has been tested on some ten Germans with the same result each time. 
igan for $\mathrm{Ph}$. D. candidates, the student's problem is to predict, from the preterite and past participle, the infinitive form, for the purpose of looking it up in the dictionary. He merely needs to recognize the tense, predict the infinitive, and look the verb up, if he doesn't know it. That is, given the expression, " $\mathrm{Er}$ ergriff," he must know that he is dealing with a preterite because of the lack of an ending (zero ending); in order to predict the infinitive, he needs to know the ablaut classes; taking either the infinitive or the preterite as a base will not helphim, for he must predict only one form, the infinitive. He does not need to know that the past participle is ergriffen, unless this is the form with which he is dealing. Such a student is not predicting the totality of verb inflections from one base form, he is predicting one base form from any other form encountered. From these arguments results the fact that our prediction must be conditioned by the purpose for which it is to be used. To be of use for recognition, however, our prediction must be made from both the past participle and the preterite, however, so that it is not truly a prediction, in that no base form is taken.

If we use Pollard's predictions, along with the added restrictions, our degree of certainty is fairly good. It is doubtful if such a set of rules could be profitably used in the classroom, however. If they are to be used, the best approach is to wait until a verbform illustrating one of the restrictions comes up naturally in the course of classroom teaching, let us say: leistete. The student can then be informed, if he improperly forms the preterite liest, that leisten is a weak verb, since its stem ends in a consonant cluster.

If one wants to use a set of predictions such as Halle's, one must include the past participle stem in the predictions, if they are to be used in a class designed for a reading knowledge. This is best done, of course, by merely setting down the traditional ablaut classes. If one wants to take a different base from the present infinitive, it is probably best to use the past participial base, since prediction from it offers much fewer irregularities than a prediction from the preterite base. For example, it is certain that the preterite of gerufen must be rief, and that the present stem must be ruf-, since only a verb of the seventh class could have a participle in $\mathrm{C}-u$-C. This would allow us to predict the preterite and present stems of 
almost all the seventh class verbs. Thus, gebraten must have the preterite briet, since $\mathrm{C}-a$-t is a pattern unknown to the sixth class. The same could be said for geheissen, geschlafen, geraten, etc. The ending -en tells the student that the verb is not weak. Actually, one might maintain that analogies in German would follow the direction past participle $\rightarrow$ preterite and present according to the rule of Kurylowicz, mentioned above, and this is supported by historical fact. ${ }^{6}$ It should be noted, however, that it is extremely impractical to take a base other than the infinitive, since this would entail rewriting our dictionaries, text-books, etc.

To sum up the foregoing arguments: the technique of prediction seems promising; one cannot apply this technique, however, without first determining the trend of analogy, if recall and creation of original sentences is desired; if passive recognition is desired, the trend of analogy can be ignored.

The fact that the trend of analogy in modern German is in the direction of forming weak preterites, rather than forming strong preterites (backte for buk, schaffte for schuf [Who says schïfe for the subjunctive any more?], etc.), seems to indicate that Pollard is right when he says that we should start out with only weak verbs. ${ }^{7}$ The fact that some strong verbs are among the most common verbs in the language may make this difficult, but it is not impossible. If the strong verbs are not to be memorized, it is my contention that the best means of learning them is oral chanting of the "Ablautsreihen." This should be done at any rate to lighten the student's load of memorization. This should, at least, prevent "false" analogies. It should also help the student who uses one of the recent text-books which neglect word-counts. Thus he would learn patterns which could be applied to most verbs, instead of learning some few verbs, which would perhaps not pattern for him, and some of which he perhaps would never use again. It is my belief that it is best to begin with weak verbs, learn these and their consonantal and

\footnotetext{
${ }^{6}$ This could be founded by saying that the past participle performed the function of the present stem in imperatives such as: "Stillgestanden!" In the first and second classes, the preterite has the vocalism of the participle, rather than the vocalism of the former singular preterite.

${ }^{7}$ This is doubted by Woods, "The Weak Verb - How to Recognize It in the Infinitive," p. 175, but the reasons adduced by him do not bear on the problem.
} 


\section{PREDICTION IN TEACHING THE GERMAN VERB}

vocalic structure, and then proceed to the strong verbs by setting down and orally chanting the ablaut classes. The student should be required to memorize each aberrant verb form. In the section on the weak verb, numerous verbs of the type weilen, which are to be considered weak because of the root structure /C-a-l/ (cf. above, page 3), should be given, so that the student gets a feeling for the difference between the type in nasals and liquids and the type in consonants other than nasals and liquids. ${ }^{8}$ Thus the student's memorization is lessened, and the length of time necessary for him to attain a "feeling for the language," a familiarity with its innate structure, is shortened. In the process of thus teaching the verbs, it is well to use Pollard's prediction classes and the restrictions mentioned wherever they are useful; they may, of course, be taught without being overtly mentioned by being exemplified in the exercises.

The concept of prediction, if properly used in perfecting techniques for the teaching of foreign languages, should prove one of the most valuable tools afforded language teachers by linguistic science.

\footnotetext{
${ }^{8}$ In this case, it is interesting to notice the reaction of native Germans to such fictitious verbs as *" deilen," *"schmeilen," * fielen," *"grielen." By a "random" sample of six Germans (two of them German teachers, to be sure), such verbs were always considered to be weak. A fictitious verb like * "bieren" was felt by four to be strong, by two to be weak. *"Bingen" was felt to be strong by all. * "Reisten" was felt to be weak by all. Although no systematic attempt was made to determine "feeling" by asking for the preterite and past participle of fictitious verbs, it is felt that these tests do afford us useful information, and that the results warrant future study. It seems that the German predicts also on the basis of the vocalic and consonantal structure of the stem.
} 